\title{
THE USE OF COMBINING DIALOGICAL THINKING AND HIGHLIGHTING STRATEGY TO IMPROVE STUDENTS' READING COMPREHENSION OF NARRATIVE TEXT
}

\author{
Salmon J Hukom \\ Dosen pada Program Studi Pendidikan Bahasa Inggris FKIP-Unpatti
}

\begin{tabular}{l} 
ARTICLE INFO \\
\hline Article History: \\
Accepted 05-03-2018 \\
Available online 02-04-2018
\end{tabular}

Keywords:

Dialogical Thinking,

Highlighting, Reading

Comprehension

\begin{abstract}
As a receptive skill, reading plays important role since it helps the readers to enhance their knowledge and also entertain them in their leisure time. In comprehending the text, foreign readers including EFL learners always face problems. Besides lack of vocabulary has become major problem, the strategy that use by teachers in teaching reading is sometimes monotonous. Other reason is that the strategy is not appropriate with the kind of text. In teaching narrative, for example, the teachers should select suitable strategy which can be used by students to comprehend that text easily. In this article, the writer wants to introduce the use of combination Dialogical Thinking and Highlighting strategy in teaching narrative text. In Dialogical Thinking, students learn to reflect and think critically about central story issue, while Highlighting gives students opportunities to mark important ideas in reading. This combination is worthy since it attracts students' attention to the very specific information in reading passage. Moreover, the students are easy to find the answers for certain kind of questions.
\end{abstract}

\section{INTRODUCTION}

Like writing that needs process, readers also needs process in understanding the text in order to be fluent readers. According to Nunan (2003) reading is a fluent process of readers combining information from a text and their own background knowledge to build meaning. Furthermore, Seyler (2004) gives opinion that reading is 
the process of obtaining or constructing meaning from a word or cluster of words. Reading isnot only reading a text or something that is written, but also getting new vocabularies, knowing thing and increasing knowledge.

In context of teaching reading, the curriculum of junior and senior high schools in Indonesia stresses on abilities of students to comprehend reading text. However, many students have less knowledge in comprehending the text. Thus, in helping the students, there are some text types at schools that must be taught, one of them is narrative text.

During some observation in some junior and senior high schools in Ambon, the use of teaching strategy always has become major problem. In teaching reading, narrative text for example, the teachers use monotenous teaching strategy and implement inappropriate teaching strategy in their teaching. Therefore, the writer keens on introducing combination between Dialogical Thinking and Highlighting Strategy in teaching narrative text.

\section{THEORETICAL OF READING}

\section{The Essense of Reading}

Reading is a complex activity that involves both perception and thought. Reading consists of two related processes: word recognition and comprehension. Word recognition refers to the process of perceiving how written symbols correspond to one's spoken language. Comprehension is the process of making sense of words, sentences and connected text. On the other hand, Tadros (2014) defines reading as the process of constructing meaning from written texts. It is a complex skill requiring the coordination of a number of interrelated sources of information. He also states that reading is the process of constructing meaning through the dynamic interaction among: (1) the reader's existing knowledge; (2) the information suggested by the text being read; and (3) the context of the reading situation. In addition, Department of School Education (1997) states reading is the process of constructing meaning from written text.

Longman Dictionary of Applied Linguistic state reading is as: "Perceiving a written text in order to understand its contents. This can be done silently (silent reading). The understanding that result is called reading comprehension. Saying a written text aloud (oral reading). This can be done with or without understanding of the content."

\section{Reading Comprehension}

According to Grabe and Stoller (2013), comprehension is the ultimate goal of all reading. That is ability to understand a text underlies all reading task. Thus main idea comprehension should be at the core of all reading instruction. Reading comprehension is one of the pillars of the act of reading. When a person reads a text he engages in a complex array of cognitive processes. He is simultaneously using his awareness and understanding of phonemes (individual sound "pieces" in language), phonics (connection between letters and sounds and the relationship between sounds, letters and words) and ability to comprehend or construct meaning from the text. This 
last component of the act of reading is reading comprehension. Simply put, reading comprehension is the act of understanding what you are reading. While the definition can be simply stated the act is not simple to teach, learn or practice. Reading comprehension is an intentional, active, interactive process that occurs before, during and after a person reads a particular piece of writing.

According to Webster's Dictionary, comprehension is "the capacity for understanding fully; the act or action of grasping with the intellect." Webster also tells us that reading is "to receive or take in the sense of (as letters or symbols) by scanning; to understand the meaning of written or printed matter; to learn from what one has seen or found in writing or printing. There are two elements that make up the process of reading comprehension: vocabulary knowledge and text comprehension. In order to understand a text the reader must be able to comprehend the vocabulary used in the piece of writing. If the individual words don't make the sense then the overall story will not either. Reading Comprehension is the understanding of the written word, the understanding of the content that is being read, and the construction of meanings of the text. Reading is a purposeful and active process. A reader reads to understand, to remember what is understood and put the understanding to use.

Carrel (1988) states that reading is a receptive language process where meaning decodes, from author's thinking. Reading comprehension is incredibly complex and multifaceted. Reading comprehension strategies must be taught over an extended period of time by parents and teachers who have knowledge and experience using them. It might seem that once a child learns to read in the elementary grades he is able to tackle any future text that comes his way. This is not true. Reading comprehension strategies must be refined, practiced and reinforced continually throughout life. Even in the middle grades and high school, parents and teachers need to continue to help their children develop reading comprehension strategies. As their reading materials become more diverse and challenging, children need to learn new tools for comprehending these texts. Content area materials such as text books and newspaper, magazine and journal articles pose different reading comprehension challenges for young people and thus require different comprehension strategies.

\section{Narrative Text}

Kane (2000) gives explanation of the narrative text. According to him narrative is a meaningful sequence of events told in words. The sequence always involves timing. The events of what happened, in order that the other: for example, in the story there is a flash back. Characters and action are essential elements of each story. Action is often presented in the form of plots. Stories can be very long and complicated, with lots of character, plot complex, and subtle interpenetration of characters, actions, and settings.

Unlike other texts, narrative text has very unique generic structure and its language features. The generic structure of narrative text is explained as follow. 
- ORIENTATION

It tells the audience about who is in the story, when the story is taking place and where the action is happening.

- COMPLICATION

It sets off a chain of events that influence what will happen in the story.

- RESOLUTION

The characters finally sort out the complication.

- CODA

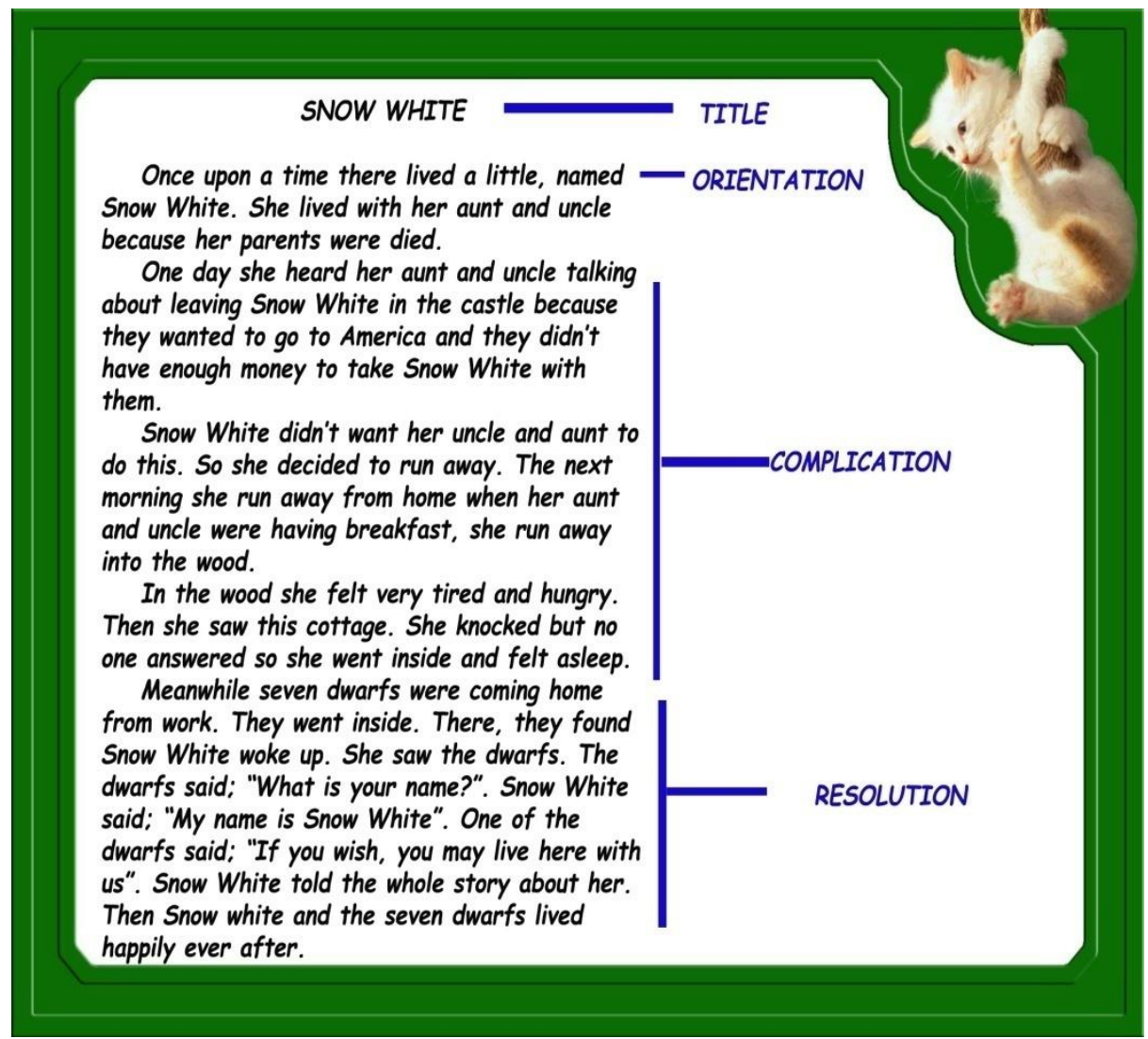

The following is the language features of narrative text.

- Past tense (killed, drunk,etc)

- Adverb of time (Once upun a time, one day, etc)

- Time conjunction (when, then, suddenly, etc)

- Specific character. The character of the story is specific, not general. (Cinderella, Snow White, Alibaba, etc)

- Action verbs. A verb that shows an action. (killed, dug, walked, etc)

- Direct speech. It is to make the story lively. (Snow White said,"My name is Snow White). The direct speech uses present tense.

(quoted from English for v.i.p, https://adeulfayani.wordpress.com/narrative-text-2/) 


\section{Dialogical Thinking}

The terms dialogical thinking means there is talks but it should be based on the result of thinking process first. Acording to Davis and Davis in Edisawati (2013) state that dialogical thinking involves seeing andbeing able to evaluate different point of viewat the same time. In addition, Commerays cited by Edisawati states that dialogical thinking while reading through discussion and collaboration, students learn to reflect and think critically about central story issue.

In context of teaching and learning activity, dialogic teaching is a technique that teachers use to help students effectively meet learning goals or accomplish tasks through dialogue. Alexander in Gupta and Lee (2015) claimed that "dialogic teaching harnesses the power of talk to stimulate and extend pupils' thinking and advance their learning and understanding." He also believes that dialogic teaching is both just any teacher initiated talk such as the question-answer and listens-tell routines, nor the casual conversation. According to Alexander, “in dialogic classrooms children don't just provide brief factual answers to test or recall questions, or merely spot the answer which they think the teacher wants to hear. Instead, when teachers use dialogic teaching, students are guided to narrate, explain, analyses, speculate, imagine, explore, evaluate, discuss, argue, justify, and they ask questions of their own.

Moreover, Gibbsons cited by Gupta and Lee (2015)explained that dialogic teaching promotes students' exploration of ideas. According to her, "it creates shared understanding and space for students to explore new concepts, clarify understandings, and perceptions, not dominated or controlled by a single person, so that participants address their comments, questions, and statements directly to each other."

\section{Advantages of Dialogical Thnking}

The advantages of dialogical thinking strategy are to engaging students directly to think and open ended. And dialogicalthinking will engage students in reflectionand critical thinking. Students have different point of view about the text based on theirbackground knowledge.

\section{Steps in Dialogical Thinking}

To make students become more familiar with dialogical thinking strategy,there are some steps of dialogical thinking based on Manzo and Manzo in Edisawati (2013) they state that there are two phases of dialogical thinking strategy as follows:

\section{Reading phase:}

1. Select a story that is intriguing and lends itself to discussion from more than one perspective.

2. Conduct a reading lesson that ensures that students .

\section{Discussion phase}

1. Identify a central question that has twopossible perspectives.

2. Divide the board under the centralquestion to reflect each side, orperspectives

3. Invite students to take one position orthe other

4. Invite students to undertake an in-depthexploration of the story in search ofreason that can classified on the boardunder the words "TRUTH" as true (T),false (F), or depends (D), and under theword "SUPPORT" as relevant (Y) ornot relevant (N).

5. Accept all reason given so that they canbe evaluated for truth and relevancy. 
6. Allow students the opportunity to saywhat they have come to believe as aresult of the dialogical examination.

\section{Highlighting Strategy}

Highlighting strategy is the strategy that used in marking important ideas in reading. According to O'Donnell (2004) Annotating, or marking (highlighting) the text to identify important information and record the reader's ideas. He also points out that Annotating helps readers reach a deeper level of engagement and promotes active reading. Moreover, Johnson, Nist, and Hogrebe cited by Engler and Berger said that in general it appears that highlighting "plays a useful if limited role in studying": it helps students to distinguish between levels of importance in text and to remember main ideas. The use of properly highlighted text aids recall.

Based on Harvey and Goudv is in Edisawati (2013) state that to effective highlight text,reader need to read the text, think about itand make conscious decision about what theyneed to remember and learn. In addition, he also states that highlighting is valuable intensive readingstrategy, both for comprehension monitoring while reading and for review after reading. This strategy helps students to remember the important information in the text and easy to find everything that students want to read.

\section{Advantage of Highlighting}

According to Edisawati (2013) Highlighting strategy has advantages for the students. She said that the advantages of highlighting strategy is to help students focus important information and important idea in text. When students highlight the text, students increase their concentration in reading. This helps student to rememberabout the idea that the students want.

\section{Disadvantage of Highlighting}

According to Yue L Carole, et.al (2014), there are some weaknesses of highlighting, they are One argument is that students often do notknow how to highlight effectively, so such activity primarily amounts to a mechanism fortracking progress and does not involve deeper processing. Another relevant factor is whether students are accustomed to using a highlight. Forcing readers who never use highlighters to do so may interfere with their learning and prevent them from employing the type of encodingtechniques they usually find beneficial.

Additionally, students' metacognitive beliefs about highlighting may limit its effectivenessas a learning tool. Students who rely on highlighters and think they are particularly effective, for example, may suffer from an illusion of knowing or competence. Specifically, such students may process highlighted material in a less meaningful way when re-reading than if that material were not highlighted. While rereading, such students may only quickly glance over highlighted text, incorrectly assuming that because they have already highlighted that information, it is deeply encoded in memory, a misbelief that is probably supported by the apparent processing fluency that learners would experience during such rereading. 


\section{Steps in Highlighting Strategy}

There are several stages of highlighting (Jones, 2006), they are

1. Students read through the selection first.

2. Students reread and begin to highlight main ideas and their supporting details.

3. Students highlight only the facts which are important or the key vocabulary not the entire sentence.

4. After highlighting, students look at what they have highlighted

\section{Procedures of Combining Dialogical Thinking and Highlighting Strategy in Teaching Narrative Text}

The following is the procedure of applying Combining Dialogical Thinking and Highlighting Strategy in Teaching Reading (adopted from Edisawati, 2013).

\section{Preparation}

Before doing the activities, the teachers have to make some preparations like bellow;

1. Teacher selects the material

2. The teacher should prepare the lessonplan

3. Teacher should prepare the media for teaching

4. Time allocation

5. Teaching goal

\section{Procedures of Teaching}

\section{Pre-Teaching Activities}

a. The teacher greets the students by saying good morning, good afternoon,and good day and so on.

b. The teacher checks the students'attendance list

c. Teacher gives some pictures to brainstorm students background knowledge

\section{Whilst-Teaching Activities}

\section{1) Exploration}

a. Teacher shows the reconstruct the story line using pictures.

b. Teacher writes the central question onthe chalkboard.

c. Teacher divides the board under thecentral question to reflect each side, orperspective. Central question : why did the man kill the goose?

d. Teacher asks to the students to take one position or the other.

e. Teacher invite students to undertake anin dept exploration on the board underwords "truth" as true (T), false (F), ordepend (D), and under the word"SUPPORT" as relevant $(\mathrm{Y})$ or notrelevant $(\mathrm{N})$.

f. Teacher accepts all reasons of students,so that can be evaluated for truth andrelevancy.

g. Teacher allows students to say whatthey have come to believe as a result ofdialogical examination.

h. Teacher distributes the text for students and asks students to read the text carefully.

i. Teacher explains about language feature and generic structure of the text

j. Teacher explains that highlighting is useful for identifying the most important

$\mathrm{k}$. Teacher asks students to highlight the important information from paragraph in the text. 


\section{2) Elaboration}

a. Students read the text narrative carefully.

b. Students highlight the main idea of paragraph

c. Students identify the generic structure

d. Students identify language features with highlight the key word.

e. Students highlight the key ideas andphrases what they want to remember.

\section{THE GOOSE THAT LAID THE GOLDEN EGG}

Long long time ago, there once was a very poor farmer. So poor he lived in an old tumble-down

pigsty in the middle of nowhere with only acorns and the odd goose egg to eat and a bale of straw for his bed. His name was Attacus Greeb.

Now Attacus Greeb hadn't always been poor. He'd inherited a large and prosperous farm from his father and he'd owned land as far as the eye could see. But Attacus Greeb was a lazy man. "So over the years, instead of working for a living he'd simply sold off his possessions. He'd sold almost everything his father had given him - his house, his land, his horses, his pigs, his cattle and all he was left with was one single goose, who lived with him.

The next morning Attacus Greeb awoke to a glittering dawn. It was so light and bright he had to shield his eyes. But it wasn't the sunlight shining, he could hardly believe what he saw, it was a gigantic, glorious..."Golden Egg!" "You clever girl! Ha ha Ho ho! We'll be rich! Rich beyond our dreams! That's what I need to be happy."

And then he had an idea."How I wish I could have all the golden eggs at once," he thought, "instead of just one a day. Then I would surely be happy.

"So the next morning he ordered his cook to kill the goose and open it up so he could take out all the eggs at once - but, of course, to his horror there was nothing inside the poor goose....and there would be no golden eggs again. And Attacus Greeb ended up back in his tumble-down pigsty - just where he belonged!

Those who have plenty want more and so lose all they have.

f. The students answer the questionsrelated to the information on the text.

1. Why is the Attacus Greeb so poor?

2. Why does not Attacus sell hisgoose?

3. How does Attacus become rich?

4. How does he end up being pooragain?

5. What makes Attacus cut open hisgoose?

3) Confirmation

a. The teacher and the students discuss the result of the elaboration.

b. The teachers lead the students to elaborate their comprehension about the story

c. The teacher leads the students to make conclusion of the material.

\section{Post-Teaching Activities}

a. The teacher evaluates the student achievement.

b. The teacher gives feedback for the students' achievement.

\section{G. Conclusion}

Based on the previous explanation in preliminary study and theories it can be concluded that teaching reading with the different genre needs appropriate strategies. Good and professional teachers should explore more in accomodating their students' needs including implementing various kinds of teaching strategies. Like in teaching narrative text, combination between Dialogical Thinking and Highlighting Strategy in teaching narrative text has some advantages and appropriate in teaching 
narrative text. Besides that these strategies facilitate students easily to find the answer in order to comprehend the content of the passage.

\section{REFERENCE}

Carrell, P. L. 1985. Facilitating ESL reading by teaching text structure. TESOL Quarterly

Edisawati, Erin. 2013. Teaching Reading Narrative Text By Combining Dialogical Thinking And Highlighting Strategies For XI Grade Students Of Senior High School. Jurnal Pendidikan Bahasa Inggris, Vol. 2, No.1, STKIP PGRI, Sumatera Barat

Engler,Steven, and Berger, Benjamin. Reading in colors Highlingting For Active Reading.

English for v.i.p. Narrative Text. Taken from quoted from English for v.i.p, https://adeulfayani.wordpress.com/narrative-text-2/)

Grabe, William and Stoller Fredericka L. 2002. Teaching and Researching Reading. London: Pearson Education Longman.

Guptha, and Lee, Lea Guang. 2015. Dialogical Teaching Appoach with English Langguage Leanners to Enhance Oral Language Skills in the Content Areas. International Journal Of Language and Linguistic, vol: 2, No. 5

Jones, R. (2006). Strategies for Reading Comprehension: Selective Underlining. Retrieved 2008, April from http://www.readingquest.org/strat/underline.html

Nunan, David. 2003. Practical English Language Teaching. New York: The McGrawHill. O’ Donnell, Carol Porter. 2004, English Journal Vol. 93, No.5

Seyler, U. Dorothy. 2004. The Reading Context: Developing College Reading Skill. New York: Pearson Education.

Tadros, Lori Connors. 2014. Definitions and Approaches to Measuring Reading Proficiency. CEELO FAST FACT

Yue, Carole L, et al. 2014. Highlighting and Its Relation to Distributed Study and Students' Metacognitive Beliefs. Educ. Psychol. Rev 